\title{
Effect of dietary supplementation with heat-treated canola meal on ruminal nutrient metabolism in lactating dairy cows
}

\author{
S. J. Krizsan, ${ }^{1}$ H. Gidlund, F. Fatehi, ${ }^{2}$ and P. Huhtanen \\ Department of Agricultural Research for Northern Sweden, Swedish University of Agricultural Sciences, SE-901 83 Umeå, Sweden
}

\begin{abstract}
An experiment was conducted to quantify the effects of incremental levels of heat-moisture-treated canola meal (TCM) fed to dairy cows on the relationship between ruminal nutrient digestion and milk production. Experimental diets were fed to 4 multiparous rumencannulated Nordic Red cows, averaging (mean \pm standard deviation) $681 \pm 54.8 \mathrm{~kg}$ of body weight, $111 \pm 16$ $\mathrm{d}$ in milk, and $29.1 \pm 9.1 \mathrm{~kg}$ of milk/d at the start of the study, in a Latin square design with four 21-d periods. The 4 experimental dietary treatments consisted of a basal diet of grass silage and crimped barley, and 3 diets in which the crimped barley was replaced with TCM, giving 3 incremental levels of protein supplementation. Nutrient flow was quantified by the omasal sampling technique using 3 markers $(\mathrm{Cr}, \mathrm{Yb}$, and indigestible neutral detergent fiber). Continuous infusion of ${ }^{15} \mathrm{~N}$ was used to label bacterial crude protein. Additionally, ruminal sampling and evacuations and measurements of total-tract digestibility were conducted. The experimental diets provided 132, 148, 164, and $180 \mathrm{~g}$ of crude protein $/ \mathrm{kg}$ of dry matter. The increased level of TCM linearly increased dry matter intake from 15.1 to $16.6 \mathrm{~kg} / \mathrm{d}$ and energy-corrected milk yield from 21.0 to $25.6 \mathrm{~kg} / \mathrm{d}$. The increased proportion of TCM when substituting barley with TCM was associated with greater total-tract digestibility of neutral detergent fiber and potentially digestible neutral detergent fiber, which could be explained by increased digestion rate of potentially digestible neutral detergent fiber. Omasal flow of nonammonia $\mathrm{N}$ naturally increased with greater dietary TCM inclusion, but the increased intestinal supply of rumen-undegradable protein was partly offset by diminished microbial protein synthesis when feeding
\end{abstract}

Received January 21, 2017.

Accepted June 20, 2017.

${ }^{1}$ Corresponding author: Sophie.krizsan@slu.se

${ }^{2}$ Current address: Department of Animal Science, Campus of Agricultural and Natural Resources, University of Tehran, Karaj, Tehran, Iran 31587-77871. more TCM. This was also reflected in a decreased proportion of milk protein from ruminal bacterial protein when TCM supplementation increased.

Key words: canola meal, dairy cow, microbial protein, milk protein

\section{INTRODUCTION}

Feeding protein supplements represents a significant cost to the dairy farm, but is still advantageous because of the positive response in milk production. Although increasing dietary $\mathrm{CP}$ concentrations increases milk yield, there is an environmental concern due to substantially decreased milk N efficiency (Broderick, 2003; Ipharraguerre and Clark, 2005). Reducing the rumen degradability of protein supplements is a strategy applied to increase the supply of dietary AA to the small intestine. This concept assumes improved milk production from increased AA supply to the lactating dairy cow. However, the relevance of this concept can be questioned, despite an aim to also improve $\mathrm{N}$ utilization efficiency. Santos et al. (1998) found increased milk production in only $17 \%$ of comparisons between soybean meal (SBM) and supplements with a high concentration of RUP. In similar comparisons, Ipharraguerre and Clark (2005) found small differences $(-2.5$ to $+2.8 \%)$ in milk yield between feeding solvent-extracted SBM and other protein supplements high in RUP. Furthermore, following a meta-analysis of large North European and North American data sets, Huhtanen and Hristov (2009) concluded that ruminal CP degradability (according to NRC, 2001) is not an important factor in predictions of milk protein yield or milk N efficiency.

Several reasons are possible for the moderate production responses observed with increased RUP concentration of protein supplements when fed to dairy cows. Feeding more RUP increases the amount of nonammonia, nonmicrobial N (NANMN) that is available for absorption in the small intestine, but can instead decrease the amount of rumen microbial NAN (Clark et al., 1992). Ipharraguerre and Clark (2005) found a 7\% decrease in passage of microbial NAN to the small in- 
testine with increased RUP supplementation. Furthermore, it could be speculated that any treatment that reduces the ruminal degradability of a feed could also make some AA unavailable to the cow, due to Maillard reactions between $\mathrm{AA}$ and carbohydrates in the heating process (Van Soest, 1994). For example, heat treatment of canola meal has been shown to decrease the concentration of Lys (Moshtaghi Nia and Ingalls, 1995; Dakowski et al., 1996). A third reason for the lack of production response with increased RUP supplementation could be due to the discrepancy between RUP predictions and in vivo results. Broderick et al. (2010) found that RUP estimated with the NRC (2001) model overestimated the flow of NANMN by $26 \%$ and underestimated microbial NAN flow compared with measurements using the omasal sampling technique in cannulated lactating dairy cows. They suggest that the overestimation might be due to errors from using the in situ technique, which assumes that the soluble protein fraction is completely degraded.

In Northern Europe, where grass silage is the foundation of dairy cow diets, canola meal has shown greater potential than SBM to increase milk production (Shingfield et al., 2003; Gidlund et al., 2015). The hypothesis in the present study was that increased flow of NANMN to the omasum with increased amount of solvent-extracted, heat-moisture-treated canola meal (TCM) could be at the expense of reduced microbial NAN flow. To test this hypothesis, the supply of CP was increased by gradually replacing crimpled barley with TCM. Feeding incremental levels of TCM allowed in-depth study of the effects of CP supplementation in typical dairy cow diets in Northern Europe, in relation to ruminal digestion and microbial protein synthesis, and the origin of the $\mathrm{N}$ incorporated into milk protein.

\section{MATERIALS AND METHODS}

All animals were registered and cared for according to guidelines approved by the Swedish University of Agricultural Sciences Animal Care and Use Committee and the National Animal Research Authority, and the experiment was carried out in accordance with the laws and regulations controlling experiments performed with live animals in Sweden.

\section{Animal Management, Experimental Design, and Diets}

This experiment used 4 multiparous lactating Nordic Red cows, averaging (mean $\pm \mathrm{SD}$ ) $681 \pm 54.8 \mathrm{~kg}$ of $\mathrm{BW}, 111 \pm 16 \mathrm{DIM}$, and $29.1 \pm 9.1 \mathrm{~kg}$ of milk/d at the start of the study. All cows were fitted with a $10-\mathrm{cm}$ ruminal cannula (Bar Diamond, Inc., Parma, ID). The cows were housed in tie-stalls bedded with sawdust, had free access to water and salt blocks throughout the experiment, and were offered feed twice daily, at 0600 and $1800 \mathrm{~h}$. Orts were recorded once daily and feeding rate was adjusted to yield orts of approximately $10 \%$ of intake, except during the $4 \mathrm{~d}$ of sampling from the omasum when intake was restricted to $95 \%$ of ad libitum intake to minimize between- and within-day variations in intake due to intensive sampling. Experimental methodologies and milk production results of this experiment have already been reported in a paper comparing sampling sites for ruminal flow measurements by Fatehi et al. (2015).

This study included 4 dietary treatments, in which crimped barley was replaced with 4 incremental levels of TCM supplementation in grass silage-based diets [none (B) and low (CL), medium (CM), and high (CH) dietary canola meal inclusion]. The diets were supplied to the cows according to a Latin square design in 4 experimental periods. The silage was prepared from the primary and regrowth of a second-year sward consisting of timothy (80\%; Phleum pratense) and red clover (20\%; Trifolium pratense). The TCM was a commercial solvent-extracted and heat-moisture-treated protein supplement (ExPro-00SF, Aarhus Karlshamn AB, Malmö, Sweden) containing some added fat and minerals. Rations were prepared manually each day, and silage and concentrate were fed separately. The DM concentration of the grass silages and concentrate ingredients was determined twice and once a week, respectively, for adjustment of the dietary forage to a concentrate ratio of 60:40 on DM basis.

\section{Sampling Procedures and Preparation of Digesta and Milk Samples}

Each experimental period lasted for $21 \mathrm{~d}$, with the last $10 \mathrm{~d}$ used for sample collection. Total DMI was measured between d 12 and 21, and total-tract digestibility of the diets was determined by spot sampling of feces during d 18 to 21. The average results from acidinsoluble ash (Van Keulen and Young, 1977) and indigestible NDF (iNDF; Huhtanen et al., 1994) marker methods were used to estimate total-tract digestibility.

Two rumen evacuations were conducted, at d 12 and $14,4 \mathrm{~h}$ after and $1 \mathrm{~h}$ before the morning feeding, respectively, to give a representative estimate of the rumen pool size. An arithmetic mean of at least 2 evacuations is recommended when animals are only fed twice daily (Huhtanen et al., 2007). The rumen evacuation technique is based on assumptions of a steady-state rumen pool size and no disturbance of the normal rumen function (Robinson et al., 1987). During the evacuations, 
particulate and fluid matter were separated, weights were recorded, and a rumen sample was reconstituted based on the recorded proportions and stored at $-20^{\circ} \mathrm{C}$ until oven drying and analysis.

After the last rumen evacuation, in situ bags were placed in the rumen of the experimental cows after morning feeding and milking. During the first 3 periods, dried samples of grass silage were incubated to determine the effect of TCM level on the degradation rate of NDF in an imbalanced Latin square design. The silage sample used for the in situ determination of NDF degradation rate was composed of samples collected from a dairy cow production trial by Gidlund et al. (2015). Samples of $2.0 \mathrm{~g}$ were weighed into polyester bags with pore size $38 \mu \mathrm{m}$ and a pore area equal to $31 \%$ of the total surface (Saatifil PES 38/31, Saatitech S.p.A., Veniano, Como, Italy). The internal dimensions of the bags and sample size were adjusted to give a sample size to surface area ratio of $10 \mathrm{mg} / \mathrm{cm}^{2}$. All bags were pre-soaked in approximately $37^{\circ} \mathrm{C}$ tap water before placement in the rumen. The polyester bags of the last 4 time points were introduced in reverse sequence into the rumen of each cow, starting at $0800 \mathrm{~h}$, and incubated for 24, 48, 72, and $96 \mathrm{~h}$. Bags for 3, 6, and $12 \mathrm{~h}$ of incubation were inserted into the rumen at the same time as the 24 -h time point bag. All bags except for those the first 3 time points were removed from the rumen at the same time. After removal from the rumen, the bags were washed and treated according to the procedure described by Krizsan et al. (2013). The incubation residues were analyzed for NDF using heat stable $\alpha$-amylase and sodium sulfite (Mertens et al., 2002) in an Ankom ${ }^{200}$ Fiber Analyzer (Ankom Technology Corp., Macedon, NY) and NDF was expressed free of residual ash. Duplicate 0-h samples of the silage were soaked in tap water (approximately $37^{\circ} \mathrm{C}$ ), and thereafter followed the same procedures as described for the other bags.

Continuous infusion of the flow markers Yb-acetate $(2.8 \mathrm{~g} / \mathrm{d}$ of $\mathrm{Yb})$ and Cr-EDTA $(2.8 \mathrm{~g} / \mathrm{d}$ of $\mathrm{Cr})$ was started on d 15 in each period. The Cr-EDTA was prepared as described by Binnerts et al. (1968). Marker infusion was continued until the last digesta sample was collected on d 21. Also from d 15, infusion of $10 \%$ atom excess $\left({ }^{15} \mathrm{NH}_{4}\right)_{2} \mathrm{SO}_{4}$ [Sigma Aldrich (Isotec), Miamisburg, $\mathrm{OH}]$, providing $186 \mathrm{mg} / \mathrm{d}$ of ${ }^{15} \mathrm{~N}$, was conducted using a peristaltic pump (ISMATEC Reglo Digital, IDEX Health and Science SA, Glattbrugg, Switzerland) assembled with the individual lines providing the flow marker infusate directly into the rumen of each cow. The infusion started at least $60 \mathrm{~h}$ before the first digesta sample collection in all periods, to allow uniform distribution of ${ }^{15} \mathrm{~N}$ from incorporation of ${ }^{15} \mathrm{NH}_{3}$ in the ruminal microbial pools (Broderick and Merchen,
1992). Before starting the infusion of ${ }^{15} \mathrm{~N}$, a sample of ruminal digesta was taken from each cow in every period and stored at $-20^{\circ} \mathrm{C}$ for later determination of ${ }^{15} \mathrm{~N}$ background.

Digesta flow was estimated using the triple marker method described by France and Siddons (1986). Indigestible NDF, which is mainly associated with the large particle fraction (Ahvenjärvi et al., 2003), Yb concentrated in the small particle digesta phase, and $\mathrm{Cr}$ following the fluid phase (Downes and McDonald, 1964) were used in combination to calculate digesta flow. The omasal sampling technique was used to collect 12 digesta samples from the omasum on d 18 to 21, with 4-h intervals between the 3 sampling occasions each day, to cover sampling hourly during a complete 12 -h feed cycle. On the last $3 \mathrm{~d}$, sampling occasions were moved $1 \mathrm{~h}$ later than on the previous day. Feces samples (approximately $250 \mathrm{~g}$ ) were collected on the same days and time points as the omasal digesta samples. Feces grab samples were directly pooled per cow during collection in each period.

The individual omasal digesta samples were separated into large particles (LP), small particles (SP), and a fluid phase (FP), according to the procedure described by Krizsan et al. (2010). The separated digesta phases were stored frozen until dried and milled. Due to limited freeze-drying capacity, LP was oven-dried, whereas SP and FP were freeze-dried. The LP phase was milled through 2.0- and 1.0-mm screens to give samples of 2 different sizes, and the SP phase was ground to pass through a 2.0-mm screen using the same cyclone mill (Cyclotec 1093 Sample mill, Foss Analytical A/S, Hillerød, Denmark). To obtain SP representative using a screen size of $2.0 \mathrm{~mm}$ in a cutter mill, the samples were ground with pestle and mortar and manually sieved through a 2.5-mm sieve. All FP samples were ground with pestle and mortar.

At the end of each of the four 12-h sampling days, bacteria were isolated from the daily omasal digesta composites from every cow, using the method described by Krizsan et al. (2010) with slight modifications. The supernatants from the $1,000 \times g$ centrifugations that aimed to separate liquid- and particle-associated bacteria from feed particles were combined to give 1 bacterial sample. A pooled bacterial isolate was thereafter separated and cleaned by high-speed centrifugation, as described by Krizsan et al. (2010). The resulting bacterial pellets were stored at $-20^{\circ} \mathrm{C}$ until freeze-dried. Bacterial composites were made by pooling equal amounts of sample DM from the 3 sampling days.

Samples of ruminal fluid were collected on 8 sampling occasions from all experimental cows during d 21. The ruminal fluid was taken from 3 locations in the midventral sac of the rumen of each cow. Samples were 
transferred to a pre-warmed thermos flasks previously flushed with $\mathrm{CO}_{2}$ using a metal filter probe connected to light vacuum at 0 (just before feeding), 1.5, 3, 4.5, $6,7.5,9$, and $10.5 \mathrm{~h}$ after feeding. The samples were strained through 2 layers of cheesecloth, followed by immediate measurement of $\mathrm{pH}$. Thereafter, $2 \mathrm{~mL}$ of strained fluid was transferred into 4 tubes of $5 \mathrm{~mL}$ for later analysis of VFA and ruminal $\mathrm{NH}_{3}$. All sample tubes were stored at $-20^{\circ} \mathrm{C}$. Ruminal fluid samples were later thawed, pooled on a volume basis within day, and analyzed for VFA. Individual ruminal fluid samples from the different time points were analyzed for $\mathrm{NH}_{3}$.

The procedures used for milk yield recording and milk sampling for composition analysis are reported in the companion paper by Fatehi et al. (2015). The ${ }^{15} \mathrm{~N}$ enrichment of milk protein was measured in representative milk samples collected and pooled within morning and afternoon milkings on d 12 to 14 for background concentration and on d 18 to 21 for microbial incorporation. From day to day, milk samples were stored in 1-L plastic cans at $8^{\circ} \mathrm{C}$ until sampling was completed, after which the samples were stored at $-20^{\circ} \mathrm{C}$. The samples were thawed and milk protein was precipitated according to Hristov and Ropp (2003), modified to sediment the milk protein pellet by centrifuging at $17,700 \times g$ for $15 \mathrm{~min}$ at $5^{\circ} \mathrm{C}$. The milk protein pellet was freezedried and analyzed for abundance of ${ }^{15} \mathrm{~N}$ atom percent excess (APE) and NAN, as later described for feces and digesta samples.

\section{Indigestible NDF and Chemical Analyses}

Concentration of iNDF in all feed, particulate fractions of digesta samples, and feces samples was determined following a 288-h in situ incubation (Huhtanen et al., 1994) in the rumen using 2 cows. The 2 Nordic Red cows used for this purpose were fed a diet consisting of $60 \%$ grass silage and $40 \%$ concentrate (mainly composed of crimped barley and canola meal; ExPro00SF, Aarhus Karlshamn AB, Malmö, Sweden) on a DM basis. Samples were analyzed according to recommendations by Krizsan et al. (2015), using polyester bags with pore size $6 \mu \mathrm{m}$ and a pore area equal to $5 \%$ of the total surface (07-6/5 Sefar Petex, Sefar AG, Heiden, Switzerland). Indigestible NDF was expressed exclusive of residual ash.

The dried individual feces samples and digesta phases were further analyzed for DM, Yb, and Cr. Feed samples were analyzed for DM. The dried individual feed, feces, and reconstituted true digesta samples from all 3 sampling sites were analyzed for OM, NDF, N, NAN, and ${ }^{15} \mathrm{~N}$. The dried milk protein pellet was also analyzed for NAN and ${ }^{15} \mathrm{~N}$. Residual moisture of all samples was determined by oven drying for $16 \mathrm{~h}$ at $105^{\circ} \mathrm{C}$. Ash concentration was determined by ignition of the dried sample at $500^{\circ} \mathrm{C}$ for $4 \mathrm{~h}$. The samples were analyzed for NDF using heat-stable $\alpha$-amylase (Mertens et al., 2002) in an Ankom ${ }^{200}$ Fiber Analyzer (Ankom Technology Corp.). Ash was determined in the bag residues and NDF was expressed free of residual ash. Concentration of $\mathrm{N}$ was determined by Kjeldahl digestion of $1.0 \mathrm{~g}$ sample in $12 \mathrm{M}$ sulfuric acid using Foss Tecator Kjeltabs $\mathrm{Cu}$ (Höganäs, Sweden) in the Block Digestion 28 system (SEAL Analytical Ltd., Mequon, WI), with determination of total $\mathrm{N}$ by continuous flow analysis using an Auto Analyzer 3 (SEAL Analytical Ltd.). The abundance of ${ }^{15} \mathrm{~N}$ and concentrations of NAN were analyzed with a Flash 2000 Organic Elemental Analyzer interfaced with an Isotope Ratio Mass Spectrometer Delta V Advantage (Thermo Fisher Scientific Inc., Waltham, MA). Samples were prepared and $\mathrm{NH}_{3}$ volatilized as described by Krizsan et al. (2010). Samples were analyzed in duplicate and samples with similar ${ }^{15} \mathrm{~N}$ enrichment were analyzed as groups to minimize ${ }^{15} \mathrm{~N}$ carryover between samples. Individual digesta phases and feces samples were analyzed for $\mathrm{Yb}$ and $\mathrm{Cr}$ using inductively coupled plasma optical emission spectroscopy on a Perkin-Elmer Optima 7300 DV (Perkin Elmer, Shelton, CT). Approximately $1.5 \mathrm{~g}$ of $\mathrm{DM}$ of sample was combined with $10 \mathrm{~mL}$ of a solution containing $65 \% \mathrm{wt} / \mathrm{vol}$ of purified $\mathrm{HNO}_{3}$. The samples were boiled in Kjeltec tubes in a block digester system (Tecator Digestion Auto, Foss Analytical A/S) with stepwise increasing temperature: $1 \mathrm{~h}$ at $60^{\circ} \mathrm{C}, 1 \mathrm{~h}$ at $100^{\circ} \mathrm{C}$, and finally $4 \mathrm{~h}$ at $125^{\circ} \mathrm{C}$. After $2 \mathrm{~h}$ at $125^{\circ} \mathrm{C}$, an additional $5 \mathrm{~mL}$ of the $\mathrm{HNO}_{3}$ solution was added. The samples were diluted to a final volume of $50 \mathrm{~mL}$ with distilled water after cooling.

Composite bacterial samples and background samples of ruminal digesta, from each cow in every period, were analyzed for NAN and ${ }^{15} \mathrm{~N}$ as described for feces and digesta samples. Additionally, DM and ash content were determined in the composite bacterial samples as described above.

The individual VFA concentrations in ruminal fluid samples were determined using a Waters Alliance 2795 HPLC system with Waters 2414 RI detector (Waters Corporation, Milford, MA) as described by Ericson and André (2010), and $\mathrm{NH}_{3}$ according to the method provided by the SEAL Analytical (method no. G-102-93 multitest MT7) on the AutoAnalyzer 3 (SEAL Analytical, Mequon, WI).

\section{Calculations}

Passage rate $\left(k_{p}\right)$ of iNDF was determined using the flux/compartmental pool method (Ellis et al., 1994) as follows: 
$\mathrm{k}_{\mathrm{p}}(\% / \mathrm{h})=100 \times$ flux of indigestible component into the compartment $(\mathrm{kg} / \mathrm{h}) /$ rumen pool of indigestible component $(\mathrm{kg})$.

The calculation of $\mathrm{k}_{\mathrm{p}}$ of potentially digestible NDF (pdNDF) was based on Equation [1] and the flux was estimated from the fecal output rather than the intake of the component. Thereafter, rate of digestion $\left(\mathrm{k}_{\mathrm{d}}\right)$ of pdNDF was calculated by subtracting $k_{p}$ from the rate of intake of pdNDF (calculated from pdNDF intake/h divided by rumen pdNDF pool). Turnover time of NDF was calculated based on the same assumption:

NDF turnover $(\mathrm{h})=24 \times$ rumen pool of NDF $(\mathrm{kg}) /$

$$
\text { intake of NDF }(\mathrm{kg}) \text {. }
$$

The in situ NDF degradation was evaluated using the simple model described by Ørskov and McDonald (1979):

$$
\mathrm{D}(\mathrm{t})=\mathrm{a}+\mathrm{b} \times\left(1-e^{-\mathrm{k}_{\mathrm{dIS}} \times \mathrm{t}}\right)
$$

where $\mathrm{D}(\mathrm{t})=$ the proportion of NDF degraded at time $\mathrm{t}$ of incubation, $\mathrm{a}=$ intercept representing the portion of NDF that had disappeared at time $0, \mathrm{~b}=$ potentially digestible $\mathrm{NDF}$ fraction, $\mathrm{k}_{\mathrm{dIS}}=$ fractional rate of degradation of fraction $b$ from in situ technique $(1 / h)$, and $\mathrm{t}=$ time.

Dry matter flows were calculated using the triplemarker method. The method requires the same number of markers as physically separated digesta phases. The true digesta composition was solved by matrix calculation based on marker concentrations in the digesta phases and daily marker doses according to Armentano and Russell (1985). Daily marker doses were estimated from feces output. Nutrient flows were calculated from nutrient composition in reconstituted true digesta samples and DM flows. To calculate true digestibility of OM, the flow of OM was corrected for VFA flow according to the equation by Huhtanen et al. (2010), and the flow of DM, OM, and NAN was corrected for microbial DM, OM, and NAN flow, respectively. Total NAN flow was assumed to be composed of bacterial NAN (also contains protozoal N) and NANMN. The bacterial NAN flows were calculated from ${ }^{15} \mathrm{~N}$ enrichment above the background as

bacterial NAN flow $(\mathrm{g} / \mathrm{d})=$ NAN flow $(\mathrm{g} / \mathrm{d})$

$$
\times \mathrm{TD}{ }^{15} \mathrm{~N}(\mathrm{APE}) / \text { bacterial }{ }^{15} \mathrm{~N}(\mathrm{APE}),
$$

where $\mathrm{TD}{ }^{15} \mathrm{~N}(\mathrm{APE})={ }^{15} \mathrm{~N}$ enrichment of the reconstituted true digesta sample above background and bacterial ${ }^{15} \mathrm{~N}$ (APE) is ${ }^{15} \mathrm{~N}$ enrichment of bacterial sample above background. The NANMN flow was calculated as the difference between total NAN flow and total bacterial NAN flow.

Calculation of ${ }^{15} \mathrm{~N}$ transformations used ${ }^{15} \mathrm{~N}$ enrichments determined above background and followed Equations [5]-[12]:

milk protein $\mathrm{N}$ from ruminal bacterial NAN $(\%)=$ $100 \times{ }^{15} \mathrm{~N}$ enrichment of milk protein $\mathrm{N}(\mathrm{APE}) /$

$$
\text { bacterial }{ }^{15} \mathrm{~N} \text { (APE), }
$$

milk protein $\mathrm{N}$ from ruminal NAN $(\%)=$ $100 \times{ }^{15} \mathrm{~N}$ enrichment of milk protein $\mathrm{N}(\mathrm{APE}) /{ }^{15} \mathrm{~N}$ enrichment of ruminal NAN (APE),

milk protein $\mathrm{N}$ from feed protein $\mathrm{N}(\%)=$ $100 \times($ milk protein $\mathrm{N}$ from ruminal NAN - milk protein $\mathrm{N}$ from ruminal bacterial NAN), [7] milk protein $\mathrm{N}$ from body turnover $\mathrm{N}(\%)=$ $100 \times(1-$ milk protein $\mathrm{N}$ from ruminal NAN $),[8]$ recovery of ${ }^{15} \mathrm{~N}$ in milk $(\%)=$ $100 \times{ }^{15} \mathrm{~N}$ in milk $(\mathrm{g} / \mathrm{d}) /{ }^{15} \mathrm{~N}$ infused $(\mathrm{g} / \mathrm{d})$,

Absorbed ${ }^{15} \mathrm{~N}$ in the reticulorumen (\%) = $100 \times\left[{ }^{15} \mathrm{~N}\right.$ infused $(\mathrm{g} / \mathrm{d})-{ }^{15} \mathrm{~N}$ flow to the omasum $(\mathrm{g} / \mathrm{d})] /{ }^{15} \mathrm{~N}$ infused $(\mathrm{g} / \mathrm{d})$,

${ }^{15} \mathrm{~N}$ flow to the omasum $(\mathrm{g} / \mathrm{d})=100 \times \mathrm{N}$ flow to the omasum $(\mathrm{g} / \mathrm{d}) \times{ }^{15} \mathrm{~N}$ enrichment

$$
\text { of omasal NAN (APE), }
$$

Ruminal $\mathrm{N}$ balance $(\%$ of $\mathrm{N}$ intake $)=$ $100 \times[\mathrm{N}$ intake $(\mathrm{g} / \mathrm{d})-\mathrm{NAN}$ flow $(\mathrm{g} / \mathrm{d})] /$

$$
\mathrm{N} \text { intake }(\mathrm{g} / \mathrm{d}) \text {. }
$$

\section{Statistical Analysis}

The data were analyzed for treatment effects using the General Linear Model of SAS (version 9.2, SAS Inst. Inc., Cary, NC) by applying a model correcting for the effect of cow, period, and diet: 


$$
\mathrm{Y}_{\mathrm{ijk}}=\mu+\mathrm{C}_{\mathrm{i}}+\mathrm{P}_{\mathrm{j}}+\mathrm{D}_{\mathrm{k}}+\varepsilon_{\mathrm{ijk}}
$$

where $Y_{\mathrm{ijk}}$ is the dependent variable, $\mu$ is the mean for all observations, $\mathrm{C}_{\mathrm{i}}$ is the effect of cow $\mathrm{i}, \mathrm{P}_{\mathrm{j}}$ is the effect of period $\mathrm{j}, \mathrm{D}_{\mathrm{k}}$ is the effect of diet $\mathrm{k}$, and $\varepsilon_{\mathrm{ijk}} \sim N\left(0, \sigma_{e}^{2}\right)$ is the random residual error, with an expected mean of zero and $\sigma_{e}^{2}$ as the constant variance. Polynomial contrasts were included for evaluation of linear and quadratic responses to TCM level. The data on $\mathrm{pH}$ and $\mathrm{NH}_{3}$ measurements were evaluated in a repeated measurements model using the Toeplitz function in Mixed procedures (cow within period was used as subject). The model accounted for the effects of cow, period, diet, time, and interactions between diet and time.

\section{RESULTS}

\section{Diet Composition and Production}

Ingredient and chemical composition of the 4 experimental diets is presented in Table 1. The basal grass silages were relatively well-fermented, and differences were observed between the diets in chemical composition that reflected the increased supplementation of TCM at the expense of the crimped barley.

Total DMI increased linearly $(P=0.02)$ from 15.1 to $16.6 \mathrm{~kg} / \mathrm{d}$ with increased TCM level (data in this paragraph are not presented in tables). Furthermore, increased level of TCM linearly increased yield of ECM, from 21.0 to $25.6 \mathrm{~kg} / \mathrm{d}(P=0.03)$, and milk protein yield $(P<0.01)$. The $\mathrm{N}$ efficiency decreased from 33.9 to $27.0 \%$ and the concentration of MUN increased from 8.5 to $13.5 \mathrm{mg} / \mathrm{dL}(P<0.01)$ with increased TCM level.

\section{Rumen Fermentation}

The quadratic response to TCM level was not significant $(P \geq 0.19)$ for any parameter of ruminal metabolites and therefore only linear effects are presented in Table 2. No changes $(P=0.41)$ occurred due to diet in total VFA concentration, but the molar proportions of individual VFA were slightly altered (increased propionate and decreased butyrate; $P \leq 0.05)$ with increased

Table 1. Ingredient and diet composition of the 4 experimental diets

\begin{tabular}{|c|c|c|c|c|c|c|c|}
\hline Item & \multicolumn{4}{|c|}{$\operatorname{Diet}^{1}$} & \multicolumn{3}{|c|}{ Ingredient } \\
\hline Silage & 544 & 549 & 561 & 552 & & & \\
\hline Crimped barley & 441 & 357 & 271 & 198 & & & \\
\hline Canola $\mathrm{meal}^{3}$ & 0 & 78.9 & 154 & 235 & & & \\
\hline $\mathrm{NaCl}$ & 3.42 & 3.38 & 3.30 & 3.36 & & & \\
\hline $\mathrm{DM}, \mathrm{g} / \mathrm{kg}$ & 411 & 427 & 440 & 465 & 232 & 611 & 848 \\
\hline $\mathrm{OM}$ & 926 & 921 & 917 & 912 & 910 & 976 & 918 \\
\hline $\mathrm{CP}$ & 132 & 148 & 164 & 180 & 142 & 122 & 328 \\
\hline Crude fat $^{5}$ & 21.3 & 26.0 & 30.5 & 35.5 & $\mathrm{NA}^{5}$ & 23.6 & 83.7 \\
\hline $\mathrm{NDF}$ & 340 & 351 & 364 & 368 & 545 & 145 & 279 \\
\hline Indigestible NDF & 79.9 & 84.4 & 88.6 & 92.7 & 103 & 54.9 & 106 \\
\hline
\end{tabular}

${ }^{1}$ Control diet (B) without canola meal, and with low (CL), medium (CM), and high (CH) levels of dietary canola meal inclusion achieved by replacing crimped barley.

${ }^{2}$ Average silage composition of the first and second cut timothy and red clover silages used in the experiment. Fermentation quality: pH 3.70 , lactic acid 105, acetic acid 23, propionic acid 2.6, and butyric acid $0.3 \mathrm{~g} / \mathrm{kg}$ of DM, and $\mathrm{NH}_{3}-\mathrm{N} 45 \mathrm{~g} / \mathrm{kg}$ of $\mathrm{N}$.

${ }^{3} \mathrm{~A}$ commercial heat-treated protein supplement of canola meal (ExPro-00SF, Aarhus Karlshamn AB, Malmö, Sweden).

${ }^{4}$ Effekt Hög Zn, Lantmännen Lantbruk AB, Stockholm, Sweden. Content: 17\% Ca, 3.5\% P, 9.5\% Mg, 7\% Na. Provides (g/kg): 5 g of Zn, 2.3 g of Mn, $0.18 \mathrm{~g}$ of I, $0.04 \mathrm{~g}$ of $\mathrm{Co}, 0.8 \mathrm{~g}$ of $\mathrm{Cu}, 0.04 \mathrm{~g}$ of Se, 250,000 IU of vitamin A, 80,000 IU of vitamin $\mathrm{D}_{3}, 6.5 \mathrm{~g}$ of vitamin $\mathrm{E}$.

${ }^{5}$ Values for the silage $(20 \mathrm{~g} / \mathrm{kg}$ of DM) taken from tables (Spörndly, 2003), those for concentrate ingredients analyzed directly.

${ }^{6}$ Not analyzed.

${ }^{7}$ Calculated according to Spörndly (2003).

${ }^{8}$ Protein balance in the rumen. Describes how much nitrogen is available to the microbes in relation to the soluble carbohydrates supplied from the feed. Calculated according to Spörndly (2003). 
Table 2. Effect of increased level of treated canola meal on ruminal fermentation

\begin{tabular}{|c|c|c|c|c|c|c|}
\hline \multirow[b]{2}{*}{ Item } & \multicolumn{4}{|c|}{$\operatorname{Diet}^{1}$} & \multirow[b]{2}{*}{ SEM } & \multirow{2}{*}{$\frac{P \text {-value }}{2}$} \\
\hline & $\mathrm{B}$ & CL & $\mathrm{CM}$ & $\mathrm{CH}$ & & \\
\hline$\overline{\mathrm{pH}}$ & 6.59 & 6.54 & 6.56 & 6.47 & 0.033 & 0.02 \\
\hline $\mathrm{NH}_{3}, \mathrm{~m} M$ & 4.13 & 5.60 & 6.48 & 6.84 & 0.549 & $<0.01$ \\
\hline Total VFA, $\mathrm{m} M$ & 93.7 & 92.1 & 94.4 & 95.3 & 1.89 & 0.44 \\
\hline Acetic acid, $\mathrm{mmol} / \mathrm{mol}$ & 665 & 661 & 655 & 660 & 6.2 & 0.47 \\
\hline Propionic acid, $\mathrm{mmol} / \mathrm{mol}$ & 172 & 177 & 186 & 191 & 5.8 & 0.04 \\
\hline Butyric acid, $\mathrm{mmol} / \mathrm{mol}$ & 124 & 123 & 122 & 113 & 2.7 & 0.03 \\
\hline Isovaleric acid, $\mathrm{mmol} / \mathrm{mol}$ & 24 & 24 & 23 & 23 & 1.4 & 0.40 \\
\hline Valeric acid, $\mathrm{mmol} / \mathrm{mol}$ & 15 & 15 & 14 & 14 & 0.6 & 0.18 \\
\hline
\end{tabular}

TCM level in the diet. Ruminal pH slightly decreased, whereas ruminal $\mathrm{NH}_{3}$ concentration increased $(P \leq$ $0.02)$, with increased TCM level. Furthermore, an interaction $(P<0.01)$ was observed between time and diet for both ruminal $\mathrm{pH}$ and $\mathrm{NH}_{3}$. For $\mathrm{pH}$ measurements, the significant interaction reflected a diet difference in terms of a sharper drop in $\mathrm{pH}$ directly after feeding for the $\mathrm{CL}$ and $\mathrm{CH}$ diets compared with the other 2 diets (results not presented). Ruminal $\mathrm{NH}_{3}$ concentrations increased after feeding, with the highest values generally observed for the $\mathrm{CH}$ diet and the lowest values for the diet without TCM (results not presented).

\section{Ruminal Outflow and Digestibility of OM and Fiber}

The quadratic response to TCM level was not significant $(P \geq 0.10)$ for any of the intake, flow, or digestibility parameters, and therefore only linear effects are presented in Table 3. Intake of OM, NDF, and pdNDF linearly increased $(P<0.01)$ with increased level of TCM in the diet (Table 3 ). Feeding more TCM tended $(P=0.08)$ to increase omasal flow of NDF linearly, but decreased ruminal true digestibility of OM. The totaltract digestibility of NDF and pdNDF increased $(P \leq$ 0.02) with higher TCM level.

Table 3. Effect of increased level of treated canola meal on intake, flow, and digestibility of OM, NDF, and potentially digestible NDF (pdNDF)

\begin{tabular}{|c|c|c|c|c|c|c|}
\hline \multirow[b]{2}{*}{ Item } & \multicolumn{4}{|c|}{ Diet $^{1}$} & \multirow[b]{2}{*}{ SEM } & \multirow{2}{*}{$\frac{P \text {-value }}{\text { Linear }}$} \\
\hline & B & CL & $\mathrm{CM}$ & $\mathrm{CH}$ & & \\
\hline \multicolumn{7}{|l|}{ Intake, $\mathrm{kg} / \mathrm{d}$} \\
\hline $\mathrm{OM}$ & 13.9 & 14.2 & 15.0 & 15.1 & 0.20 & $<0.01$ \\
\hline $\mathrm{NDF}$ & 5.1 & 5.4 & 5.9 & 6.1 & 0.12 & $<0.01$ \\
\hline pdNDF & 3.8 & 4.1 & 4.5 & 4.6 & 0.09 & $<0.01$ \\
\hline \multicolumn{7}{|l|}{ Omasal flow, $\mathrm{kg} / \mathrm{d}$} \\
\hline $\mathrm{OM}$ & 7.5 & 8.0 & 8.0 & 8.0 & 0.38 & 0.41 \\
\hline $\mathrm{NDF}$ & 2.6 & 2.7 & 2.9 & 3.0 & 0.16 & 0.08 \\
\hline pdNDF & 1.3 & 1.3 & 1.5 & 1.4 & 0.14 & 0.58 \\
\hline \multicolumn{7}{|c|}{ Rumen digestibility, $\mathrm{g} / \mathrm{kg}$} \\
\hline Apparent $\mathrm{OM}^{3}$ & 461 & 434 & 464 & 475 & 21.0 & 0.46 \\
\hline True $\mathrm{OM}^{4}$ & 696 & 657 & 665 & 657 & 12.1 & 0.08 \\
\hline $\mathrm{NDF}$ & 491 & 503 & 514 & 518 & 26.9 & 0.48 \\
\hline pdNDF & 653 & 678 & 674 & 707 & 34.2 & 0.34 \\
\hline \multicolumn{7}{|c|}{ Total-tract digestibility, $\mathrm{g} / \mathrm{kg}$} \\
\hline $\mathrm{OM}$ & 715 & 710 & 725 & 721 & 7.5 & 0.35 \\
\hline NDF & 595 & 613 & 653 & 630 & 10.5 & 0.02 \\
\hline pdNDF & 787 & 821 & 859 & 856 & 12.9 & $<0.01$ \\
\hline
\end{tabular}

${ }^{1}$ Control diet (B) without canola meal, and with low (CL), medium (CM), and high (CH) levels of dietary canola meal inclusion achieved by replacing crimped barley.

${ }^{2}$ Probability of significant effect of linear and quadratic response to level of treated canola meal.

${ }^{3}$ Organic matter apparently digested in the rumen (flow of OM was corrected for flow of VFA).

${ }^{4}$ Organic matter truly digested in the rumen (flow of OM was corrected for microbial OM flow). 
Table 4. Effect of increased level of treated canola meal on intake, flow, and digestibility of $\mathrm{N}$, and microbial protein synthesis

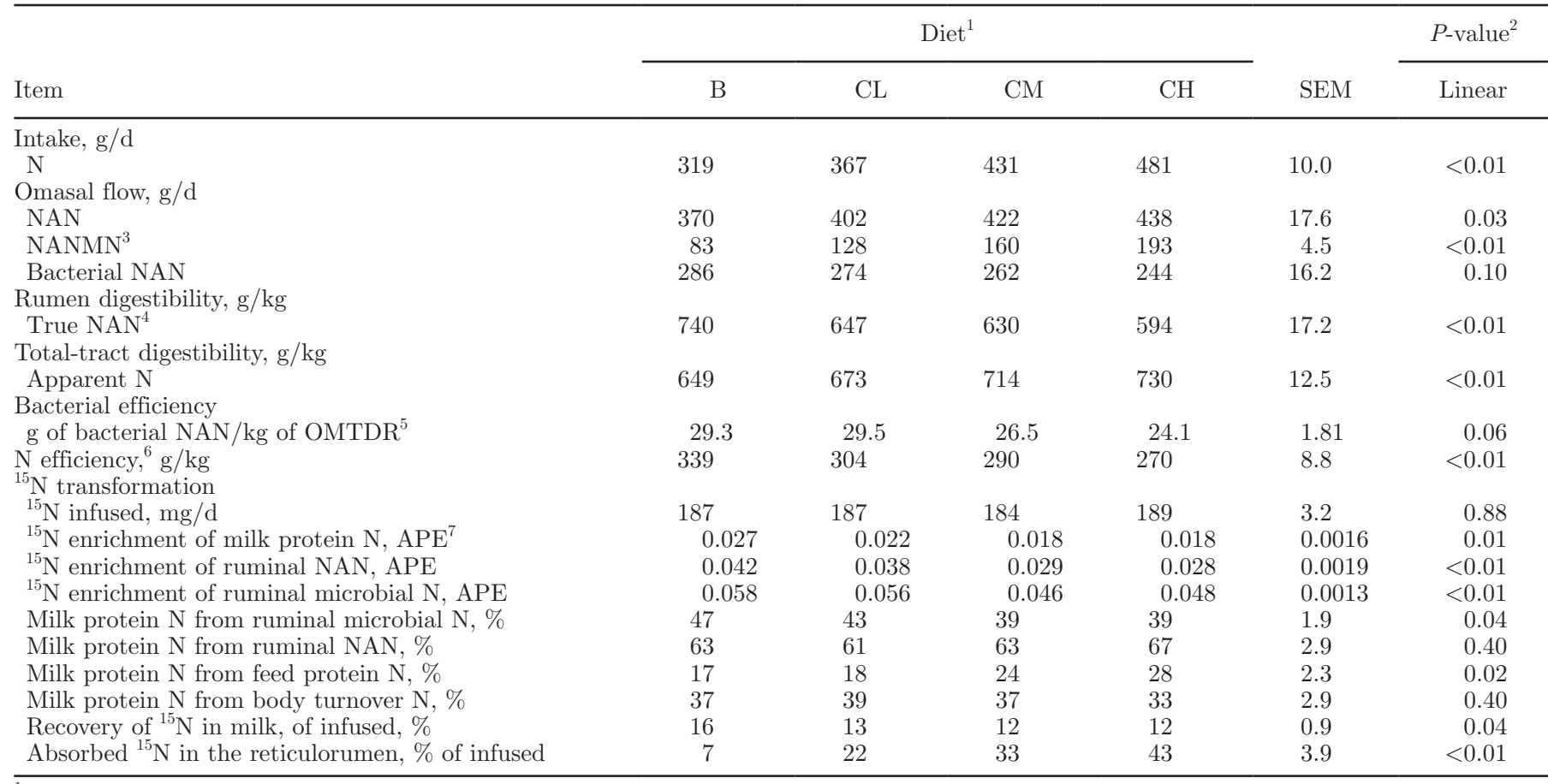

${ }^{1}$ Control diet (B) without canola meal, and with low (CL), medium (CM), and high (CH) levels of dietary canola meal inclusion achieved by replacing crimped barley.

${ }^{2}$ Probability of significant effect of linear response to level of treated canola meal. The quadratic response to level of treated canola meal was not significant for any trait $(P \geq 0.14)$.

${ }^{3}$ Nonammonia, nonmicrobial N.

${ }^{4}$ Corrected for bacterial NAN flow.

${ }^{5}$ Organic matter truly digested in the rumen (flow of OM was corrected for microbial OM flow and VFA flow).

${ }^{6} \mathrm{~N}$ efficiency $=$ milk $\mathrm{N} / \mathrm{N}$ intake.

${ }^{7}$ Atom percent excess.

\section{Ruminal Outflow and Digestibility of N Fractions and Bacterial Protein Synthesis}

The quadratic response to TCM level was not significant $(P \geq 0.14)$ for any parameter of ruminal outflow, digestibility of $\mathrm{N}$ fractions, or microbial protein synthesis, and therefore only linear effects are presented in Table 4. Intake of $\mathrm{N}(P<0.01)$ and omasal outflow of NAN $(P=0.03)$ and NANMN $(P<0.01)$ increased with increased TCM concentration. Ruminal true NAN digestibility decreased $(P<0.01)$, whereas omasal outflow of bacterial NAN and the bacterial efficiency only tended $(0.06<P<0.10)$ to decrease, with increased TCM level. Total-tract apparent $\mathrm{N}$ digestibility increased $(P<0.01)$ with increased inclusion of TCM in the diet.

\section{Incorporation of Bacterial Protein into Milk Protein}

The ${ }^{15} \mathrm{~N}$ enrichment of milk protein $\mathrm{N}$, ruminal NAN, and ruminal bacterial NAN decreased $(P \leq 0.01)$ with increased TCM level (Table 4). The estimated proportion of milk protein $\mathrm{N}$ originating from ruminal bacterial NAN decreased $(P=0.05)$ from 47 to $39 \%$ with increased TCM level, whereas the estimated proportion of milk $\mathrm{N}$ originating from dietary protein increased $(P \leq 0.05)$ from 17 to $28 \%$. Diet did not affect the proportion of milk protein $\mathrm{N}$ originating from either ruminal NAN or body $\mathrm{N}$ turnover. The recovery of the ${ }^{15} \mathrm{~N}$ infused in milk protein $\mathrm{N}$ decreased $(P \leq 0.05)$, and the proportion of ${ }^{15} \mathrm{~N}$ that was absorbed as $\mathrm{NH}_{3} \mathrm{~N}$ in the reticulorumen increased from 7 to $43 \%$, with increased TCM level.

\section{Rumen Pool Sizes and Digestion Kinetics}

The quadratic response to TCM level was not significant $(P \geq 0.27)$ for any parameter of rumen pool size and digestion kinetics and therefore only linear effects are presented in Table 5. Generally, there were few effects of increased TCM level on rumen pool size and only the rumen pool of iNDF was found to increase 
$(P=0.05)$. The $\mathrm{k}_{\mathrm{d}}$ of pdNDF increased $(P<0.01)$, whereas the $\mathrm{k}_{\mathrm{p}}$ of pdNDF tended to decrease $(P=$ $0.10)$, with more $\mathrm{CP}$ in the diets. In addition, NDF turnover time decreased linearly $(P<0.01)$ when TCM level increased.

\section{DISCUSSION}

\section{Diet Composition and Production}

Silage CP concentration was lower and the iNDF concentration was higher than in the silages used in experimental diets in the study by Gidlund et al. (2015). This resulted in a lower maximum dietary CP concentration than the original target level of $200 \mathrm{~g} /$ $\mathrm{kg}$ of DM and comparatively less pdNDF across all diets. However, the linear milk yield responses were in agreement with the results for the cows fed TCMsupplemented diets in the trial by Gidlund et al. (2015) and of canola meal-supplemented diets in the trial by Shingfield et al. (2003). It has been demonstrated that inclusion of canola meal in dairy cow rations increases DMI and yield of milk and milk protein (Huhtanen et al., 2011; Martineau et al., 2013).

Increased protein supplementation increased silage and total DMI during the ad libitum feeding period. The magnitude of responses per unit of increased dietary $\mathrm{CP}$ concentration was similar to those reported by Huhtanen et al. (2011) in a meta-analysis of protein supplementation studies with dairy cows fed grasssilage-based diets. Increased DMI has been suggested to be related to a faster rate of fiber digestion in the rumen (Oldham, 1984). This suggestion is supported by the shorter rumen turnover time of NDF and faster $\mathrm{k}_{\mathrm{d}}$ of pdNDF determined by the rumen evacuation technique for increased TCM level in the present study. However, degradation rate of silage NDF determined by ruminal in situ incubation was not influenced by the level of TCM supplementation. This suggests that the faster $k_{d}$ determined by rumen evacuation resulted from intrinsic differences in the NDF fraction in barley and TCM rather than from stimulation of cellulolytic bacteria by increased supply of AA. Increases in DMI have also been reported following postruminal infusions of protein, indicating that part of the response is related to metabolic effects, possibly mediated by improvements in the ratio of AA to energy at the tissue level. Greater intake effects of postruminal than ruminal casein infusions (Khalili and Huhtanen, 2002), and of duodenal protein infusion compared with ruminal protein or glucose infusions (Faverdin et al., 2003), support this suggestion. The lack of dietary effects on rumen DM and NDF pool sizes in the present study suggest that DMI was not limited by rumen fill for any of the diets. Rumen pool size of NDF and total chewing time increase with fill-limited diets (Khalili and

Table 5. Effect of increased level of treated canola meal on rumen pool size and digestion kinetics

\begin{tabular}{|c|c|c|c|c|c|c|}
\hline \multirow[b]{2}{*}{ Item } & \multicolumn{4}{|c|}{ Diet $^{1}$} & \multirow[b]{2}{*}{ SEM } & \multirow{2}{*}{$\frac{P \text {-value }}{2}$} \\
\hline & $\mathrm{B}$ & CL & $\mathrm{CM}$ & $\mathrm{CH}$ & & \\
\hline \multicolumn{7}{|l|}{ Rumen pool size, $\mathrm{kg}$} \\
\hline Total digesta & 78.6 & 79.6 & 80.9 & 82.0 & 2.74 & 0.38 \\
\hline DM & 8.79 & 9.08 & 8.76 & 8.86 & 0.309 & 0.94 \\
\hline $\mathrm{NDF}$ & 4.86 & 5.10 & 4.76 & 5.02 & 0.200 & 0.91 \\
\hline $\mathrm{pdNDF}^{3}$ & 3.17 & 3.12 & 3.01 & 3.00 & 0.158 & 0.42 \\
\hline $\mathrm{iNDF}^{4}$ & 1.70 & 1.99 & 1.74 & 2.02 & 0.066 & 0.05 \\
\hline \multicolumn{7}{|l|}{ Kinetics, $\% / \mathrm{h}$} \\
\hline pdNDF $\mathrm{k}_{\mathrm{d}}^{5}$ & 4.35 & 4.76 & 5.60 & 5.51 & 0.204 & $<0.01$ \\
\hline $\mathrm{pdNDF} \mathrm{k}_{\mathrm{p}}^{6}$ & 1.10 & 1.01 & 0.88 & 0.93 & 0.074 & 0.10 \\
\hline iNDF $k_{p}$ & 3.17 & 2.92 & 3.67 & 3.25 & 0.168 & 0.24 \\
\hline $\mathrm{NDF}$ turnover time, $\mathrm{h}$ & 21.8 & 21.7 & 18.4 & 19.5 & 0.55 & $<0.01$ \\
\hline \multicolumn{7}{|l|}{ NDF digestion kinetics (in situ) } \\
\hline Potential digestibility, ${ }^{7} \mathrm{~g} / \mathrm{kg}$ & 843 & 854 & 850 & 858 & 9.2 & 0.40 \\
\hline $\mathrm{k}_{\mathrm{d}}, \% / \mathrm{h}$ & 6.51 & 6.55 & 6.45 & 6.13 & 0.353 & 0.49 \\
\hline
\end{tabular}

${ }^{1}$ Control diet (B) without canola meal, and with low (CL), medium (CM), and high (CH) levels of dietary canola meal inclusion achieved by replacing crimped barley.

${ }^{2}$ Probability of significant effect of linear response to level of treated canola meal. The quadratic response to level of treated canola meal was not significant for any trait $(P \geq 0.27)$.

${ }^{3}$ pdNDF $=$ potentially digestible NDF.

${ }^{4} \mathrm{iNDF}=$ indigestible NDF

${ }^{5}$ Digestion rate.

${ }^{6}$ Passage rate.

${ }^{7}$ Determined as $\mathrm{a}+\mathrm{b}$ from fitting in situ data to the exponential equation by Ørskov and McDonald (1979). 
Huhtanen, 2002), indicating that cows can adjust their DMI when their milk yield, and consequently energy demand, increases with increased AA supply.

The milk protein yield response of $150 \mathrm{~g} / \mathrm{kg}$ incremental CP intake was slightly greater than that of $133 \mathrm{~g} / \mathrm{kg}$ for heat-treated canola meal reported in the meta-analysis by Huhtanen et al. (2011). This response was approximately $30 \%$ greater than the corresponding response to SBM in the same analysis. Higher plasma His concentrations in cows fed canola meal compared with cows fed SBM (Shingfield et al., 2003) suggest that greater production responses to canola meal can be attributed to increased supply of His. Martineau et al. (2013) concluded that protein supplements can be replaced by canola meal with positive effects on milk and milk protein production. Their study also indicated underestimation of MP supply associated with canola meal inclusion in dairy cow feed rations using the NRC model (NRC, 2001).

\section{Rumen Fermentation}

In line with findings by Jaakkola and Huhtanen (1993) for growing cattle and Moss et al. (1995) for sheep, the molar proportion of butyrate increased with increasing proportion of barley in the diet to replace grass silage. However, they did not observe any effect on molar proportion of propionate with increased dietary proportion of barley, which contradicts the general view that increased dietary starch concentration increases the proportion of propionate (Van Soest, 1994). Similarly, the results in the present study were contradictory, because the proportion of propionate increased when the proportion of barley decreased due to increased TCM supplementation. Murphy et al. (2000) reported an increase in the proportion of butyrate, but no effect on propionate, when the proportion of barley and wheat-based concentrate was increased from 50 to $70 \%$ on a DM basis. Over several years of Finnish research (>100 diets), the relationship between the proportion of concentrate (grain-based) and molar proportion of propionate is slightly curvilinear, with minimum propionate at about 20 to $30 \%$ concentrate in the diet, and about the same with forage alone or $50 \%$ concentrate (Huhtanen et al., 2013).

The increased ruminal $\mathrm{NH}_{3}-\mathrm{N}$ concentration with increased TCM level was expected, as similar results have been reported in studies investigating dietary $\mathrm{CP}$ level, for example by Olmos Colmenero and Broderick (2006) and Agle et al. (2010). The ruminal $\mathrm{NH}_{3}-\mathrm{N}$ concentration relates to microbial breakdown of AA, uptake of $\mathrm{NH}_{3}$ by ruminal microbes, and absorption of $\mathrm{NH}_{3}$ through the rumen wall. In the present study, the ruminal $\mathrm{NH}_{3}-\mathrm{N}$ concentration increased with increased
TCM, despite the simultaneous increase in absorption of ${ }^{15} \mathrm{~N}$ infused into the reticulorumen. Furthermore, because the bacterial efficiency tended to decrease, it is not likely that uptake of $\mathrm{NH}_{3}-\mathrm{N}$ by microbes increased. Therefore the main cause of the increased ruminal $\mathrm{NH}_{3}-$ $\mathrm{N}$ is likely to be increased proteolysis of the greater amount of available feed protein, and hence increased deamination of $\mathrm{AA}$ to $\mathrm{NH}_{3}$.

\section{Digestion of OM and NDF}

The lack of significant response in terms of total-tract OM digestibility to increased TCM supplementation is in agreement with conclusions in a meta-analysis by Nousiainen et al. (2009) of data from digestibility studies on dairy cows fed mainly grass silage-based diets. However, small differences in total-tract OM digestibility might be more difficult to detect in intensive metabolism studies with cannulated cows, due to lower statistical power. The trend toward reduced ruminal true OM digestibility with increased TCM supplementation was mainly due to reduced ruminal CP degradability. Total NDF digestibility increased with the level of TCM supplementation, despite increased dietary iNDF concentration. This indicates that replacement of starch with protein improves cell wall digestion by alleviating the negative effects of starch, or that increased supply of AA has a stimulatory effect on cell wall digestion, or both. It is also possible that the intrinsic rate of pdNDF digestion is faster for TCM than barley, which is supported by the results from the rumen evacuation and the in situ silage NDF degradability in the rumen (discussed earlier). In this study, it is less likely that the improved cell wall digestion with TCM supplementation was caused by decreased negative effects due to the decreased starch intake. High starch intake can decrease ruminal $\mathrm{pH}$, which is unfavorable for cellulolytic microbes. Here the $\mathrm{pH}$ was greater with more starch in the diet, so it seems that starch did not have negative effects on cellulolytic activity in the control diet.

\section{Digestion of $\mathbf{N}$}

The intake of $\mathrm{N}$ increased from 319 to $481 \mathrm{~g} / \mathrm{d}$ with stepwise replacement of crimped barley with TCM, mainly because of increased CP concentration and partly due to increased DMI. When calculated as a regression of omasal NAN flow on $\mathrm{N}$ intake, the recovery of incremental $\mathrm{N}$ in omasal $\mathrm{N}$ flow was $41 \%$. This value is less than the values of 52 and $65 \%$ calculated by Ahvenjärvi et al. (1999) for untreated and heat-moisturetreated canola meal supplements, respectively, in cows fed grass silage and cereal grain-based diets. Reduced ${ }^{15} \mathrm{~N}$ enrichment of ruminal bacteria and the decrease 
from 93 to $57 \%$ in the recovery $\left(100-\mathrm{NH}_{3}\right.$ absorption) of ${ }^{15} \mathrm{~N}$ at the omasum with increased level of TCM supplementation indicates increased $\mathrm{NH}_{3}-\mathrm{N}$ losses from the rumen and reduced net utilization of recycled $\mathrm{N}$ to bacterial $\mathrm{N}$ synthesis.

Ruminal protein degradability, estimated by assuming constant degradability for the basal diet and endogenous $\mathrm{N}$ of $0.085 \mathrm{~g} / \mathrm{kg}$ of $\mathrm{BW}^{0.75}$ (Ørskov et al., 1986), was $74 \%$ for the basal diet (silage + barley) and $42 \%$ for TCM. The protein degradability was lower than the $66 \%$ observed for canola meal in the study by Brito et al. (2007), and the $50 \%$ observed for untreated canola meal by Ahvenjärvi et al. (1999), but similar to their reported ruminal CP degradability of $41 \%$ for heat-treated canola meal. The true $\mathrm{CP}$ digestibility estimated by the Lucas test (Van Soest, 1994) using mean treatment data was $96 \pm 3.1 \%$. Huhtanen et al. (2011) reported values of 94 and $85 \%$ for the true CP digestibility of untreated and heat-treated canola meal, respectively. Low ruminal degradability of the TCM was observed in this study, but a high total CP digestibility indicated that the heat treatment to increase ruminal bypass of feed protein was effective. The treatment did not increase the indigestible protein fraction.

Bacterial NAN flow tended to decrease with increasing level of TCM supplementation, despite increased DMI and ruminal $\mathrm{NH}_{3}-\mathrm{N}$ concentration, thereby partly counterbalancing the effect of increased omasal flow of NANMN that consists of mainly undegraded feed protein with some endogenous N. Similarly, replacement of barley-oat pellets with heat-treated canola or soybean expeller has been found to decrease the efficiency of microbial $\mathrm{N}$ synthesis, despite increases in the concentrations of dietary $\mathrm{CP}$ and ruminal $\mathrm{NH}_{3}-\mathrm{N}$ (Rinne et al., 2015). Reduced microbial $\mathrm{N}$ flow with increased TCM supplementation agrees with observations by Ipharraguerre and Clark (2005) of a significant depression $(7 \%)$ in the flow of microbial $\mathrm{N}$ when SBM was replaced with RUP supplements. In an earlier review (Santos et al., 1998), high RUP diets resulted in decreased microbial synthesis in $76 \%$ of studies. Clark et al. (1992) and Firkins (1996) suggested that a shortage of energy, AA, peptides, or $\mathrm{NH}_{3}$ in the rumen can depress the growth of ruminal bacteria when RDP sources are replaced with RUP supplements. However, in the data set of Ipharraguerre and Clark (2005) the mean dietary CP concentration was $17 \%$, which should meet the requirements even when ruminal protein degradability is decreased. In the present study TCM replaced crimped barley, which can be a better energy source (rapidly digestible starch compared with protein) and also a better source of AA and peptides than TCM for ruminal microbes. Reynal and Broderick (2005) found that gradual replacement of solvent-extracted SBM with lignosulfonate-treated SBM decreased microbial $\mathrm{N}$ flow and the efficiency of microbial synthesis, and attributed these responses to decreased supply of RDP and ruminal $\mathrm{NH}_{3}-\mathrm{N}$ concentration. In the present study and in that by Rinne et al. (2015), microbial $\mathrm{N}$ flow and microbial efficiency tended to decrease despite increased dietary intake and concentration of RDP when heat-treated protein supplements were fed.

In the study by Broderick and Reynal (2009), microbial $\mathrm{N}$ and NAN flow at the omasum decreased linearly when solvent-extracted SBM was replaced with treated SBM and urea, despite increased ruminal $\mathrm{NH}_{3^{-}}$ $\mathrm{N}$ concentration. This suggests that RDP from true protein stimulates microbial $\mathrm{N}$ synthesis more than the same amount of RDP from urea and a RUP source. However, no difference was observed in microbial N flow between urea and isonitrogenous supplements of solvent-extracted canola meal and canola expeller in the study by Ahvenjärvi et al. (1999). The difference between the 2 studies could be related to the nature of the basal diet: formic-acid-treated grass silage and barley (Ahvenjärvi et al., 1999) can supply more free $\mathrm{AA}$ and peptides for microbial growth in the rumen than diets based on corn and alfalfa silages and corn (Broderick and Reynal, 2009).

In studies investigating the effects of treatments used to increase the supply of RUP, the flow of NAN was not increased despite 20 to $25 \%$ lower ruminal in situ degradability for treated compared with untreated canola meal (Robinson et al., 1994; Ahvenjärvi et al., 1999). In the present study, NAN flow to the omasum increased as a consequence of the greater amount of TCM supplementation in the diets. The study by Lebzien and Voigt (1999) using a larger data set (327 observations) supported findings in this study indicating decreased microbial NAN flow with increased TCM supplementation. Those authors developed an equation from duodenal flow data predicting utilizable CP (CP flow - endogenous protein at the duodenum) in which RUP/CP ratio had a negative effect on the coefficient calculating microbial CP flow from digestible OM intake. The effect on microbial CP flow due to increased dietary RUP concentration was greater than the decrease in the supply of fermentable substrate (Lebzien and Voigt, 1999).

The trend toward reduced microbial $\mathrm{N}$ synthesis with increased supply of TCM and other RUP sources, as discussed above, could be an explanation for the rather limited milk production responses to increased supply of RUP from treated protein supplements observed in meta-analyses (Santos et al., 1998; Ipharraguerre and Clark, 2005). 


\section{Incorporation of Bacterial Protein into Milk Protein}

Dietary CP level had a distinct effect on the incorporation of different $\mathrm{N}$ pools into milk protein, and decreased ${ }^{15} \mathrm{~N}$ enrichment of ruminal microbes with increased TCM level. Higher ${ }^{15} \mathrm{~N}$ enrichment of microbial $\mathrm{N}$ indicates more efficient conversion of $\mathrm{NH}_{3}-\mathrm{N}$ to bacterial $\mathrm{N}$ with low $\mathrm{CP}$ diets. In contrast to our results, Agle et al. (2010), who used a pulse-dose of ${ }^{15} \mathrm{~N}$, did not find any differences in ${ }^{15} \mathrm{~N}$ enrichment of ruminal microbes when feeding dietary CP levels of 12.9, 13.4, and $15.4 \%$, where the low and medium diets were deficient in RDP. However, the area under the ${ }^{15} \mathrm{~N}$ curve decreased with increased dietary CP level.

In our study, the recovery of ${ }^{15} \mathrm{~N}$ at the omasum decreased with increased level of TCM in the diet. A close relationship was observed between ${ }^{15} \mathrm{~N}$ recovery at the omasum and ruminal $\mathrm{N}$ balance: $[\mathrm{N}$ balance $(\%$ of $\mathrm{N}$ intake) $=0.717 \times{ }^{15} \mathrm{~N}$ recovery $\left.-49.2 ; \mathrm{R}^{2}=0.97\right]$. The intercept of the $\mathrm{x}$-axis $(69 \%)$ indicates that zero ruminal $\mathrm{N}$ balance was achieved when net $\mathrm{NH}_{3}{ }^{15} \mathrm{~N}$ absorption through the rumen wall was $31 \%$, which in turn indicates considerable recycling of $\mathrm{N}$.

The values for milk protein $\mathrm{N}$ derived from bacterial $\mathrm{N}$ were within the range reported by Hristov and Ropp (2003) and Agle et al. (2010). Two explanations are possible for the decreased ${ }^{15} \mathrm{~N}$ enrichment of milk protein with increased dietary $\mathrm{CP}$ level. Hristov and Ropp (2003) suggested that a smaller total flow of microbial protein to the small intestine, where it would be further absorbed and used in milk protein synthesis, is the main cause of decreased ${ }^{15} \mathrm{~N}$ enrichment in milk protein. This agrees with our results, because the bacterial NAN flow and proportion of NAN at the omasum decreased with increased dietary CP level. Hristov and Ropp (2003) also suggested that the increased milk protein yield with increased dietary CP level can dilute the ${ }^{15} \mathrm{~N}$-enriched microbial protein available for milk protein synthesis.

We assumed that the ${ }^{15} \mathrm{~N}$ enrichment ratio between milk and omasal NAN flow reflected the contribution of omasal NAN flow to milk protein synthesis. The results showed increased proportion of milk protein $\mathrm{N}$ derived from feed protein and decreased proportion of milk protein synthesis from ruminal bacterial NAN with increased TCM level. It probably corresponds to the increased ratio between the omasal flow of NANMN and bacterial NAN with increased TCM level, and also to the increased total flow of NAN at the omasum, along with the decreased recovery of ${ }^{15} \mathrm{~N}$ in milk as a proportion of the amount infused. We assumed that the ${ }^{15} \mathrm{~N}$ enrichment ratio between milk $\mathrm{N}$ and omasal NAN reflected the contribution of dietary and bacterial NAN to milk protein synthesis. The results showed that the contribution of body protein turnover was on average $37 \%$. The significant increases in background ${ }^{15} \mathrm{~N}$ enrichment between periods indicate that absorbed ${ }^{15} \mathrm{~N}$ was partly used for body protein synthesis, contributing later to milk protein synthesis. In a study by Agle et al. (2010), after a pulse dose of the marker ${ }^{15} \mathrm{NH}_{4} \mathrm{Cl}$, milk ${ }^{15} \mathrm{~N}$ enrichment had not yet decreased to background level after $6 \mathrm{~d}$, which also suggests that a substantial proportion of milk $\mathrm{N}$ is derived from the turnover of body protein.

\section{CONCLUSIONS}

Stepwise replacement of crimped barley with TCM confirmed our hypothesis that increased flow of NANMN to the omasum with increased amount of TCM is at the expense of reduced bacterial NAN flow, because both the bacterial NAN flow at the omasum and the efficiency of bacterial $\mathrm{N}$ synthesis tended to decrease. This was also reflected in the decreased proportion of milk protein originating from ruminal bacterial protein when TCM supplementation increased. The inconsistent and rather limited milk production responses to increased supply of RUP from heat-treated protein supplements can be at least partly offset by reduced efficiency of bacterial protein synthesis. As expected, the omasal flow of NAN and NANMN increased with increased TCM level. This indicates that the heat treatment applied to reduce the ruminal degradability of canola meal was successful in terms of low ruminal degradability (42\%) and high total-tract true CP digestibility (96\%).

\section{ACKNOWLEDGMENTS}

This work was supported by RuminOmics (project no. 289319 of the European Community 7th Framework Programme: Food, Agriculture, Fisheries and Biotechnology, Bucksburn, Aberdeen, UK).

\section{REFERENCES}

Agle, M., A. N. Hristov, S. Zaman, C. Schneider, P. Ndegwa, and V. K. Vadella. 2010. The effects of ruminally degraded protein on rumen fermentation and ammonia losses from manure in dairy cows. J. Dairy Sci. 93:1625-1637.

Ahvenjärvi, S., A. Vanhatalo, P. Huhtanen, and T. Varvikko. 1999. Effects of supplementation of a grass silage and barley diet with urea, rapeseed meal and heat-moisture-treated rapeseed cake on omasal digesta flow and milk production in lactating dairy cows. Acta Agric. Scand. Anim. Sci. 49:179-189.

Ahvenjärvi, S., A. Vanhatalo, K. J. Shingfield, and P. Huhtanen. 2003. Determination of digesta flow entering the omasal canal of dairy cows using different marker systems. Br. J. Nutr. 90:41-52.

Armentano, L. E., and R. W. Russell. 1985. Method for calculating digesta flow and apparent absorption of nutrients from nonrepresentative samples of digesta. J. Dairy Sci. 68:3067-3070. 
Binnerts, W. T., A. T. Vantkloo, and A. M. Frens. 1968. Soluble chromium indicator measured by a atomic absorption in digestion experiments. Vet. Rec. 82:470.

Brito, A. F., G. A. Broderick, and S. M. Reynal. 2007. Effects of different protein supplements on omasal nutrient flow and microbial protein synthesis in lactating dairy cows. J. Dairy Sci. 90:18281841.

Broderick, G. A. 2003. Effects of varying dietary protein and energy levels on the production of lactating dairy cows. J. Dairy Sci. $86: 1370-1381$

Broderick, G. A., P. Huhtanen, S. Ahvenjärvi, S. M. Reynal, and K. J. Shingfield. 2010. Quantifying ruminal nitrogen metabolism using the omasal sampling technique in cattle-A meta-analysis. J. Dairy Sci. 93:3216-3230.

Broderick, G. A., and N. R. Merchen. 1992. Markers for quantifying microbial protein-synthesis in the rumen. J. Dairy Sci. 75:2618 2632.

Broderick, G. A., and S. M. Reynal. 2009. Effect of source of rumendegraded protein on production and ruminal metabolism in lactating dairy cows. J. Dairy Sci. 92:2822-2834.

Clark, J. H., T. H. Klusmeyer, and M. R. Cameron. 1992. Microbial protein synthesis and flows of nitrogen fractions to the duodenum of dairy cows. J. Dairy Sci. 75:2304-2323.

Dakowski, P., M. R. Weisbjerg, and T. Hvelplund. 1996. The effect of temperature during processing of rape seed meal on amino acid degradation in the rumen and digestion in the intestine. Anim. Feed Sci. Technol. 58:213-226.

Downes, A. M., and I. W. McDonald. 1964. The chromium-51 complex of ethylenediamine tetraacetic acid as a soluble rumen marker. Br. J. Nutr. 18:153-162.

Ellis, W. C., J. H. Matis, T. M. Hill, and M. R. Murphy. 1994. Methodology for estimating digestion and passage kinetics of forages. Pages 682-756 in Forage Quality, Evaluation, and Utilization. G. C. Fahey Jr., M. Collins, D. R. Mertens, and L. E. Moser, ed. American Society of Agronomy, Madison, WI.

Ericson, B., and J. André. 2010. HPLC-Applications for agricultura and animal science. Pages 23-26 in Proc. 1st Nordic Feed Science Conference, Uppsala, June 22-23, 2010. SLU Repro, Uppsala, Sweden.

Fatehi, F., S. J. Krizsan, H. Gidlund, and P. Huhtanen. 2015. A comparison of ruminal or reticular digesta sampling as an alternative to sampling from the omasum of lactating dairy cows. J. Dairy Sci. 98:3274-3283.

Faverdin, P., D. M'hamed, and R. Vérite. 2003. Effects of metabolizable protein on intake and milk production of dairy cows independent of effects on ruminal digestion. Anim. Sci. 76:137-146.

Firkins, J. L. 1996. Maximizing microbial protein synthesis in the rumen. J. Nutr. 126:1347S-1354S

France, J., and R. C. Siddons. 1986. Determination of digesta flow by continous marker infusion. J. Theor. Biol. 121:105-120.

Gidlund, H., M. Hetta, S. J. Krizsan, S. Lemosquet, and P. Huhtanen. 2015. Effects of soybean meal or canola meal on milk production and methane emissions in lactating dairy cows fed grass silagebased diets. J. Dairy Sci. 98:8093-8106.

Hristov, A. N., and J. K. Ropp. 2003. Effect of dietary carbohydrate composition and availability on utilization of ruminal ammonia nitrogen for milk protein synthesis in dairy cows. J. Dairy Sci. $86: 2416-2427$

Huhtanen, P., S. Ahvenjärvi, G. A. Broderick, S. M. Reynal, and K. J. Shingfield. 2010. Quantifying ruminal digestion of organic matter and neutral detergent fiber using the omasal sampling technique in cattle - A meta-analysis. J. Dairy Sci. 93:3203-3215.

Huhtanen, P., U. Asikainen, M. Arkkila, and S. Jaakkola. 2007. Cell wall digestion and passage kinetics estimated by marker and in situ methods or by rumen evacuations in cattle fed hay 2 or 18 times daily. Anim. Feed Sci. Technol. 133:206-227.

Huhtanen, P., M. Hetta, and C. Swensson. 2011. Evaluation of canola meal as a protein supplement for dairy cows: A review and a metaanalysis. Can. J. Anim. Sci. 91:529-543.
Huhtanen, P., and A. N. Hristov. 2009. A meta-analysis of the effects of protein concentration and degradability on milk protein yield and milk N efficiency in dairy cows. J. Dairy Sci. 92:3222-3232.

Huhtanen, P., S. Jaakkola, and J. Nousiainen. 2013. An overview of silage research in Finland: From ensiling innovation to advances in dairy cow feeding. Agric. Food Sci. 22:35-56.

Huhtanen, P., K. Kaustell, and S. Jaakkola. 1994. The use of internal markers to predict total digestibility and duodenal flow of nutrients in cattle given six different diets. Anim. Feed Sci. Technol. 48:211-227.

Ipharraguerre, I. R., and J. H. Clark., 2005. Impacts of the source and amount of crude protein on the intestinal supply of nitrogen fractions and performance of dairy cows. J. Dairy Sci. 88 (E Suppl.):E22-E37.

Jaakkola, S., and P. Huhtanen. 1993. The effects of forage preservation method and proportion of concentrate on nitrogen digestion and rumen fermentation in cattle. Grass Forage Sci. 48:146-154.

Khalili, H., and P. Huhtanen. 2002. Effect of casein infusion in the rumen, duodenum or both sites on factors affecting forage intake and performance of dairy cows fed red clover-grass silage. J. Dairy Sci. 85:909-918

Krizsan, S. J., S. Ahvenjärvi, H. Volden, and G. A. Broderick. 2010 Estimation of rumen outflow in dairy cows fed grass silage-based diets by use of reticular sampling as an alternative to sampling from the omasal canal. J. Dairy Sci. 93:1138-1147.

Krizsan, S. J., F. Jančík, M. Ramin, and P. Huhtanen. 2013. Comparison of some aspects of the in situ and in vitro methods in evaluation of neutral detergent fiber digestion. J. Anim. Sci. 91:838-847.

Krizsan, S. J., M. Rinne, L. Nyholm, and P. Huhtanen. 2015. New recommendations for the ruminal in situ determination of indigestible neutral detergent fibre. Anim. Feed Sci. Technol. 205:31-41.

Lebzien, P., and J. Voigt. 1999. Calculation of utilizable crude protein at the duodenum of cattle by two different approaches. Arch. Tierernahr. 52:363-369.

Martineau, R., D. R. Ouellet, and H. Lapierre. 2013. Feeding canola meal to dairy cows: A meta-analysis of lactational responses. J. Dairy Sci. 96:1701-1714.

Mertens, D. R., M. Allen, J. Carmany, J. Clegg, A. Davidowicz, M. Drouches, K. Frank, D. Gambin, M. Garkie, B. Gildemeister, D. Jeffress, C. S. Jeon, D. Jones, D. Kaplan, G. N. Kim, S. Kobata, D. Main, X. Moua, B. Paul, J. Robertson, D. Taysom, N. Thiex, J. Williams, and M. Wolf. 2002. Gravimetric determination of amylase-treated neutral detergent fiber in feeds with Refluxing in beakers or crucibles: Collaborative study. J. AOAC Int. 85:1217-1240.

Moshtaghi Nia, S. A., and J. R. Ingalls. 1995. Influence of moist heat treatment on ruminal and intestinal disappearance of amino acids from canola meal. J. Dairy Sci. 78:1552-1560.

Moss, A. R., D. I. Givens, and P. C. Garnsworthy. 1995. The effect of supplementing grass silage with barley on digestibility, in sacco degradability, rumen fermentation and methane production in sheep at two levels of intake. Anim. Feed Sci. Technol. 55:9-33.

Murphy, M., M. Åkerlind, and K. Holtenius. 2000. Rumen fermentation in lactating cows selected for milk fat content fed two forage to concentrate ratios with hay or silage. J. Dairy Sci. 83:756-764.

Nousiainen, J., M. Rinne, and P. Huhtanen. 2009. A meta-analysis of feed digestion in dairy cows. 1 . the effects of forage and concentrate factors on total diet digestibility. J. Dairy Sci. 92:5019-5030.

NRC. 2001. Nutrient Requirements of Dairy Cattle. 7th rev. ed. National Academy of Sciences, Washington, DC.

Oldham, J. D. 1984. Protein energy relationships in dairy cows. J. Dairy Sci. 67:1090-1114.

Olmos Colmenero, J. J., and G. A. Broderick. 2006. Effect of dietary crude protein concentration on milk production and nitrogen utilization in lactating dairy cows. J. Dairy Sci. 89:1704-1712.

Ørskov, E. R., N. A. Macleod, and D. J. Kyle. 1986. Flow of nitrogen from the rumen and abomasum in cattle and sheep given protein free nutrients by intragastric infusion. Br. J. Nutr. 56:241-248.

Ørskov, E. R., and I. McDonald. 1979. The estimation of protein degradability in the rumen from incubation measurements weighed according to rate of passage. J. Agric. Sci. 92:499-503. 
Reynal, S. M., and G. A. Broderick. 2005. Effect of dietary level or rumen-degraded protein on production and nitrogen metabolism in lactating dairy cows. J. Dairy Sci. 88:4045-4064.

Rinne, M., K. Kuoppala, S. Ahvenjärvi, and A. Vanhatalo. 2015. Dairy cow responses to graded levels of rapeseed and soya bean expeller supplementation on a red clover/grass silage-based diet. Animal 9:1958-1969.

Robinson, P. H., G. R. Khorasani, and J. J. Kennelly. 1994. Forestomach and whole tract digestion in lactating dairy cows fed canola meal treated with variable levels of acetic acid. J. Dairy Sci. $77: 552-559$

Robinson, P. H., S. Tamminga, and A. M. VanVuuren. 1987. Influence of declining level of feed intake and varying the proportion of starch in the concentrate on rumen ingesta quantity, composition and kinetics of ingesta turnover in dairy cows. Livest. Prod. Sci. $17: 37-62$.
Santos, F. A. P., F. E. P. Santos, C. B. Theurer, and J. T. Huber. 1998. Effects of rumen-undegradable protein on dairy cow performance: A 12-year literature review. J. Dairy Sci. 81:3182-3213.

Shingfield, K. J., A. Vanhatalo, and P. Huhtanen. 2003. Comparison of heat-treated rapeseed expeller and solvent-extracted soya-bean meal as protein supplements for dairy cows given grass silagebased diets. Anim. Sci. 77:305-317.

Spörndly, R. 2003. Fodertabeller for idisslare. Report no. 257. The Swedish University of Agricultural Science, Uppsala, Sweden.

Van Keulen, J., and B. A. Young. 1977. Evaluation of acid insoluble ash as natural marker for digestibility studies. J. Anim. Sci. 44:282-287.

Van Soest, P. J. 1994. Nutritional Ecology of the Ruminant. 2nd rev. ed. Cornell University Press, Ithaca, NY. 